Sobre líneas.

\section{El libro-álbum} en el aula

María CRISTINA

Thompson y Alfredo

Grondona White

Buenos Aires.

Deldragón, 2016

\section{Texto e imagen ¿antinomias? El libro-álbum como punto de encuentro}

Lorena Sánchez ${ }^{\bullet}$

Universidad Nacional del Litoral

Desafíos, una palabra que a muchos nos causa un sabor especial y que María Cristina Thompson ha sabido llevar al máximo a partir de una experiencia socializadora que decidió plasmar en su libro Sobre líneas. El libro-álbum en el aula.

En este texto publicado en marzo de 2016 por Ediciones Deldragón y de la mano de Alfredo Grondona White como ilustrador, María Cristina se dedica a trazar modos de mirar distintos - y los desafíos que ello implica—, y a figurar una poética diferente como lo es la que representa el libro-álbum como producto cultural.

Concebido como su tesis de posgrado, M. Cristina Thompson delinea con total simpleza y transparencia, una experiencia socializadora de lectura de libros-álbum, — totalmente rica por donde se la mire- que se desarrolló durante un año lectivo en dos escuelas estatales de Ciudad Autónoma de Buenos Aires, con niños del Segundo Ciclo del Nivel Primario. Su pregunta orientadora, ¿cómo procesan la lectura multimodal los lectores alfabetizados que cursan $5^{\circ}$ grado en dos escuelas de entornos socioculturales diferentes?, la llevó a estructurar el libro en cuatro capítulos que intentan — desde diferentes perspectivas — responder a la misma.

Majestuosamente e iniciando con un mosaico sorprendente de voces, la autora nos presenta al libro-álbum como un producto en donde se relacionan dialógicamente dos códigos semánticos: la palabra y la imagen visual. De una forma extraordinaria, se abordará al mismo bajo diversos aportes de estudiosos de la palabra (como por ejemplo Wolfgang Iser, Hans-Robert Jauss, Laura Devetach, Louise Rosenblatt) y de estudiosos de la imagen visual (como Nelson Goodman, Ernst H. Gombrich, David Perkins, John Dewey, entre otros), para acercarnos así a una definición rica de este objeto artístico.

Partiendo de un enfoque sociocultural para pensar estrategias y técnicas didácticas que permitan llevar al aula actividades con el libro-álbum, Thompson se centra en los aportes de Lev Vygotski sobre la construcción del conocimiento inducido desde lo social, primero como proceso interpsicológico y luego transformado en intrapsicológico y define el nuevo rol del docente en su papel como mediador o guía que acompaña a los jóvenes lectores.

Entre líneas se nos invita una y otra vez, a reconsiderar las prácticas de docentes y mediadores, a abrir nuevos caminos dentro del aula, a generar sin miedos nuevas

- Profesora en Letras de la Universidad Nacional del Litoral. Estudiante avanzada de la Licenciatura en Letras de la misma Universidad. Sus temas de interés abarcan el área de los Estudios Comparados, en particular, la literatura en relación con las artes visuales. 
experiencias que despierten en los niños no solo la curiosidad intelectual, sino también la apreciación visual, el intercambio de ideas y la exploración de múltiples puntos de vista. Son las voces de los niños las que también se harán presentes, junto con sus producciones, para que evaluemos y valoricemos el papel del libro-álbum como texto multimodal.

Entramando voces, opiniones e investigaciones, lo que se remarca constantemente es la no linealidad de la propuesta de lectura que impulsa el libro-álbum. Esta colabora en ampliar la mirada del lector, quien desde su rol debe estar atento, ya que en este tipo de textos la participación del mismo se pide a gritos. Se reclama página a página la presencia de un destinatario activo y creativo, que participe de manera astuta en el proceso de decodificación, que ahonde en las lecturas sin fin que este tipo de objeto cultural y artístico brinda.

Asistimos con placer a la desafiante y novedosa propuesta de Thompson, en la que se presentan asimismo las voces de cuatro especialistas que expresan sus argumentos singulares en torno a esta experimentalidad literaria y artística. Estas voces ingresan al texto a través de un cuestionario que la autora les envió con los siguientes interrogantes:

¿Qué entiende usted por libro-álbum?

¿Cuáles serían los aportes del libro-álbum?

¿Qué recomendaría en cuanto a su lectura?

Otros comentarios que desee hacer.

Una lectura complementaria que no tiene desperdicio, de la mano de autores de la talla de Istvan Schritter, Patricia Berdichevsky, María Inés Bogomolny y Alejandra Saguier.

Sobre líneas. El libro-álbum en el aula, se nos ofrece como un texto cargado de voces, de experiencias, de encuentros, destinado a docentes, bibliotecarios, mediadores que deseen empaparse en nuevas modalidades de lectura, en donde se debe - «ver para leer»—; un texto que acompaña y alienta a quienes deseamos propiciar en los niños el desarrollo del pensamiento crítico entre otras disposiciones cognitivas, habilidades y maneras de sentir; un texto que, sin lugar a dudas, desde una experiencia personal como la que transmite la autora, permite ampliar la mirada y enriquecer la práctica docente. 